\title{
RISK FACTORS, CLINICAL MANIFESTATION AND PREVENTION OF POST-DURAL PUNCTURE HEADACHE IN THE OBSTETRIC FIELD
}

\author{
Matas Kalinauskas, Mantilè Juotkutė \\ Lithuanian University of Health Sciences
}

Keywords: analgesia, post-dural puncture headache, obstetrical anesthesia.
Summary
Introduction: Over the past decades, the number of wo- men choosing to have epidural analgesia or undergoing spinal anesthesia during labor is steadily increasing. Con- sequently, a risk for complications is increasing. Post- dural puncture headache (PDPH) is considered one of the most common complication following accidental dural puncture (ADP).
Sources and a method: A literature overview were con- ducted via search engine "PubMed (Medline)" and "Goo- gle Scholar". Randomized controlled trials, meta - analy- sis, retrospective, prospective trials and systemic reviews on PDPH were selected.
Aim of the review: To evaluate the most commonly des- cribed risk factors, clinical presentation and prevention of PDPH in the obstetric field.
Results: The occurrence of ADP during neuraxial anest- hesia reported in the literature is relatively small $-0,1-$ $1,5 \%$. PDPH is a potentially expected complication after any lumbar punction. It presents as a headache within five days of the puncture due to low cerebrospinal fluid pressure. The pain is often bilateral, located in the frontal or occipital areas. Symptoms, such as vision and hearing impairment, neck pain and nausea might follow. Usually, the symptoms fade out spontaneously within two weeks. Risk factors for PDPH are modifiable (technique of the injection and anesthesiologist's skills) and non-modifia- ble (pregnancy, low body mass index (BMI), dehydra- tion, history of PDPH). The goal of preventing PDPH is to identify and correct the risk factors associated with this condition. Main described means being equipment and experience, conservative measures, administration of epidural morphine, intravenous dexamethasone or co- syntropin, epidural blood patch and intrathecal catheter. Conclusions: 1. PDPH manifests as an orthostatic hea- dache with or without ocular, neural, hearing and other

symptoms. 2. Young pregnant women with low BMI are more likely to suffer from PDPH. 3. PDPH prevention consists of risk factor correction and proper medical techniques.

\section{Introduction}

Epidural analgesia and spinal anesthesia are frequently used in obstetric practice - over the past few decades, the number of women choosing to have epidurals during labor is steadily increasing [1]. It is suggested, that up to $80 \%$ of the women in Europe and North America give birth with neuraxial block [2]. Post-dural puncture headache (PDPH), also known as lumbar puncture headache (LPH) is one of the most commonly occurring complication following epidural or spinal anesthesia [3]. Most often the cause of PDPH is iatrogenic, although it may occur spontaneously [2]. It is proven, that PDPH is a cause for longer hospitalization, maternal distress, increased drug consumption, additional medical interventions and impaired capability to nurture the baby [4]. Past research shows, that spinal anesthesia has played a major role in the decrease of maternal mortality rates compared to endotracheal anesthesia [5].

The aim of this review is to evaluate the most commonly described risk factors, clinical presentation and prevention of PDPH in the obstetric field.

\section{Sources and a method}

This is a literature overview. Randomized controlled trials, meta - analysis, retrospective, prospective trials and systemic reviews on post-dural puncture headache were selected using search engine PubMed (Medline), using the keywords: "post-dural puncture headache", "obstetrics", "incidence", "risk factors", "prevention".

\section{Results}

Incidence. The occurrence of accidental dural puncture (ADP) during neuraxial anesthesia reported in the literature is relatively small $-0,1-1,5 \%[6,7]$. A large retrospective analysis of 43434 women, who had epidural analgesia du- 
ring labor, was done in order to determine the prevalence of PDPH. Out of all the patients, 63 events were identified and associated with PDPH $-0,15 \%$ occurrence. ADP was witnessed in 38 women, out of those 24 developed PDPH afterwards [4]. Costa et al [5] conducted a ten-year retrospective analysis of women, who received neuraxial anesthetic for labor and delivery. A total of 32655 women had neuraxial analgesia, only $298(0,9 \%)$ were diagnosed with PDPH afterwards. $21795(66,7 \%)$ received epidural anesthesia and $10249(31,4 \%)$ received spinal anesthesia. PDPH incidence was witnessed in epidural and spinal anesthesia, respectfully $224(1 \%)$ and $70(0,7 \%) .611$ patients received a combination of these two methods, which showed a higher rate of PDPH 1,3\%. Sprigge et al [8] conducted a survey of 18337 patients, who received epidural analgesia over the course of 23 years. There was an incidence of $167(0,91 \%)$ ADP's and 147 (88\%) patients developed PDPH.

Clinical manifestations. PDPH is a potentially expected complication after any lumbar punction. It presents as an orthostatic headache - meaning it is provoked by a vertical position [9]. PDPH occurs within five days of the puncture due to low cerebrospinal fluid (CSF) pressure following a CSF leak through the puncture [2]. The pain is often bilateral, located in the frontal or occipital areas [3]. Usually, symptoms, such as vision and hearing impairment, photophobia, tinnitus, neck pain and nausea follow the headache $[2,3]$

Normally, symptoms fade out within 10-14 days without any medical interventions [2]. However, a possibility of complications, such as chronic headaches, cerebral venous thrombosis, reversible cerebral vasoconstriction syndrome or subdural hematoma from traction in dural veins should be taken into consideration at any time $[3,5]$.

Risk factors. Once the spinal injection has occurred, there are various risk factors that contribute to the higher incidence of PDPH, they can be broadly categorized as modifiable and non-modifiable [10].

Modifiable factors mostly include the technique of the injection and anesthesiologist's skills. Needle parameters shape, size (i.e., larger bore spinal needles are more likely to be the cause of PDPH) and the insertion angle as well as the stylet replacement, multiple attempts and inexperience of the person who's performing the injection have previously shown to increase the rates of PDPH $[2,3,10]$.

Pregnancy and younger age have been regarded as one of the most important non-modifiable risk factors for PDPH however, this consideration might reflect the high incidence of spinal or epidural injection in a fertile women's cohort $[7,10]$. Although controversial, the risk of ADP is directly increased by the stage of labor, to be precise, women at a greater degree of cervical dilatation are more likely to feel uncomfortable and not to be able to remain still at the time of injection, hence increasing the chance of ADP and PDPH [2]. As mentioned before, young pregnant women, especially the ones with low BMI, seem to be of the greatest risk for experiencing PDPH [7]. In addition, some authors suggest that multiparous and obese women might also be more likely to suffer PDPH [5]. History of PDPH, dehydration and history of migraines also influence the rates of PDPH $[3,11,12]$.

Prevention. The goal to preventing PDPH is to identify and correct the risk factors associated with this condition. There are several studies reporting on prevention of PDPH. However, the results of which measures are the best to this day remain inconclusive [11].

1. Equipment and experience. According to literature, needle size may be the most important risk factor associated with PDPH. Bezov et al. [10] recommends to use $25-27 \mathrm{G}$ needles for epidural anesthesia, because $22 \mathrm{G}$ is more often associated with PDPH. Bigger needles leave a larger opening in the dura mater, as a result of that more CSF is lost. Furthermore, a higher incidence of PDPH was noted with less experienced residents: number of epidurals administered (PDPH incidence) $-<10(2,5 \%)$ vs $>60(1,2-1,3 \%)$.

2. Conservative measures. Arevalo-Rodriguez et al [12] systematic review of 24 trials concluded that bed rest showed no benefits compared to immediate mobilization for the prevalence of severe PDPH (low quality evidence). Furthermore, bed rest was associated with a probable increase of PDPH compared to mobilization. Fluid supplementation was also analyzed in the review. The authors concluded that in the presence of severe PDPH fluid supplementation showed an absence of benefits (low quality evidence). The effect of oral caffeine was researched in Ona et al [13] systematic review. Oral caffeine was not associated with decreased prevalence of PDPH and showed a negative effect of insomnia to patients.

3. Epidural morphine. Administering a dose of epidural morphine after a witnessed dural puncture is an effective prevention for PDPH [11]. In a systematic review morphine administration was associated with a positive effect in reducing the number of women affected by PDPH. However, adverse events, such as vomiting and nausea were higher in participants who were given morphine [13]. Bradbury et al [14] conducted a systematic review and meta - analysis and stated that epidural morphine reduced the incidence of PDPH $(p=0,014)$. A recent randomized double - blind controlled trial evaluated prophylactic intrathecal morphine injection for prevention of PDPH. The authors found that a single prophylactic morphine injection does not decrease the incidence or severity of PDPH [15]. Brinser et al [14] reviewed 80 cases where 38 women were given neuraxial 
morphine and 42 were not. There was no statistically significant difference found between the two groups for incidence and severity of headache.

4. Dexamethasone. There is conflicted information regarding the use of intravenous dexamethasone for PDPH prevention. A study of patients who underwent spinal anesthesia concluded that dexamethasone did not have any benefits for headache incidence [16]. A recent randomized double-blinded placebo-controlled trial, in which 96 patients were given $8 \mathrm{mg}$ of dexamethasone and 96 patients were given normal saline after spinal anesthesia. The incidence of PDPH and nausea were significantly lower in the dexamethasone group, respectfully $\mathrm{p}=0.002$ and $\mathrm{p}=0.015$ [17]. However, Yang et al [18] study of 307 participants who were given dexamethasone and 309 who were given placebo found no difference between the two groups for protective effect against PDPH $(\mathrm{p}=0.054)$. On the contrary. Dexamethasone increased the incidence of PDPH in the first 24 hours $(\mathrm{p}=0.016)$.

5. Cosyntropin. According to the literature, cosyntropin can reduce the number of women with PDPH [13]. A randomized controlled trial by Hakim et al [19], where 45 patients received $1 \mathrm{mg}$ of cosyntropin and 45 received placebo, showed that PDPH was significantly lower in cosyntropin group $(\mathrm{p}=0.001)$.

6. Epidural blood patch (EBP). Prophylactic EBP is one of the preventive possibilities if an ADP occurs. It involves an injection of about $20 \mathrm{ml}$ of autologous blood in the epidural space prior to removing the catheter. A randomized controlled trial with 116 patients was done to determine the effect of prophylactic and therapeutic blood patch. 60 patients were included in the prophylactic group and 56 in therapeutic. The incidence of PDPH in the prophylactic group was $18.3 \%$, while in therapeutic group PDPH was $79.6 \%$ [20]. A retrospective analysis of 298 patients that developed PDPH showed that $49.7 \%$ did not receive EBP, $42.9 \%$ received one EBP and $7.4 \%$ received two or more [5]. For patients with a difficult catheter placement, EBP may be a reasonable choice for prevention of PDPH. Although, a risk of infection has to be weighted [11].

7. Intrathecal catheter. After ADP leaving an intrathecal catheter is a viable option to prevent CSF loss. The risk of re-puncturing dura mater is less than $10 \%$ according to the literature [7]. It is recommended that an intrathecal catheter should be in place at least for 24 hours. The results of this method showed a significant decrease in PDPH $(91.9 \%$ vs $6.2 \%$ ) [11]. Russell et al [21] conducted a randomized controlled trial of 97 patients with ADP, where 47 women received a repeated epidural and 50 were converted to spinal analgesia. There was no difference between the two groups for incidence of PDPH ( $p=0.2)$. 2021 ADP management guidelines suggest inserting an intrathecal catheter after dura mater punction to decrease the chances of PDPH and decrease the need for EBP [22].

\section{Conclusions}

PDPH manifests as an orthostatic headache with or without ocular, neural, hearing and other symptoms. It is caused by low CSF pressure. PDPH should always be mentioned as a possible complication of epidural analgesia or spinal anesthesia. Young pregnant women with low BMI are more likely to suffer from PDPH, other risk factors include dehydration, obesity and staff inexperience. PDPH prevention consists of risk factor correction and proper medical techniques.

\section{References}

1. Anim-Somuah M, Smyth RM, Cyna AM, Cuthbert A. Epidural versus non-epidural or no analgesia for pain management in labour. Cochrane Database Syst Rev 2018;5(5):CD000331. https://doi.org/10.1002/14651858.CD000331.pub4

2. Sachs A, Smiley R. Post-dural puncture headache: the worst common complication in obstetric anesthesia. Semin Perinatol 2014;38(6):386-94.

https://doi.org/10.1053/j.semperi.2014.07.007

3. Plewa MC, McAllister RK. Postdural Puncture Headache. StatPearls Publishing 2021.

4. Tien JC, Lim MJ, Leong WL, Lew E. Nine-year audit of postdural puncture headache in a tertiary obstetric hospital in Singapore. J Obstet Anesth 2016;28:34-38.

https://doi.org/10.1016/j.ijoa.2016.06.005

5. Costa AC, Satalich JR, Al-Bizri E, Shodhan S, Romeiser JL, Adsumelli R, Abola RE, Steinberg ES, Bennett-Guerrero E. A ten-year retrospective study of post-dural puncture headache in 32,655 obstetric patients. Can J Anaesth 2019;66(12):14641471 .

https://doi.org/10.1007/s12630-019-01486-6

6. Abela GP, Tan T. Accidental dural puncture and post-dural puncture headache: a retrospective review in an Irish maternity hospital. Ir J Med Sci 2020;189(2):657-660. https://doi.org/10.1007/s11845-019-02139-9

7. Buddeberg BS, Bandschapp O, Girard T. Post-dural puncture headache. Minerva Anestesiol 2019;85(5):543-553.

https://doi.org/10.23736/S0375-9393.18.13331-1

8. Sprigge JS, Harper SJ. Accidental dural puncture and post dural puncture headache in obstetric anaesthesia: presentation and management: a 23-year survey in a district general hospital. Anaesthesia 2008;63(1):36-43.

https://doi.org/10.1111/j.1365-2044.2007.05285.x

9. Arshed S, Enakuaa S, Nai Q, Hossain MA, Tulpule S, Yousif A. A rare case of orthostatic headache due to spontaneous intracranial hypotension. Clin Case Rep 2015;4(2):192-194. 
https://doi.org/10.1002/ccr3.470

10. Bezov D, Ashina S, Lipton R. Post-dural puncture headache: part II--prevention, management, and prognosis. Headache 2010;50(9):1482-98.

https://doi.org/10.1111/j.1526-4610.2010.01758.x

11. Gaiser RR. Postdural puncture headache: an evidence-based approach. Anesthesiol Clin 2017;35(1):157-167.

https://doi.org/10.1016/j.anclin.2016.09.013

12. Arevalo-Rodriguez I, Ciapponi A, Roqué i Figuls M, Muñoz L, Bonfill Cosp X. Posture and fluids for preventing post-dural puncture headache. Cochrane Database Syst Rev 2016. https://doi.org/10.1002/14651858.CD009199.pub3

13. Basurto Ona X, Uriona Tuma SM, Martínez García L, Solà I, Bonfill Cosp X. Drug therapy for preventing postdural puncture headache. Cochrane Database Syst Rev 2013. https://doi.org/10.1002/14651858.CD001792.pub3

14. Bradbury CL, Singh SI, Badder SR, Wakely LJ, Jones PM. Prevention of post-dural puncture headache in parturients: a systematic review and meta-analysis. Acta Anaesthesiol Scand 2013;57(4):417-30.

https://doi.org/10.1111/aas.12047

15. Peralta FM, Wong CA, Higgins N, Toledo P, Jones MJ, McCarthy RJ. Prophylactic intrathecal morphine and prevention of post-dural puncture headache: a randomized double-blind trial. Anesthesiology 2020;132:1045-1052

https://doi.org/10.1097/ALN.0000000000003206

16. Doroudian MR, Norouzi M, Esmailie M, Tanhaeivash R. Dexamethasone in preventing post-dural puncture headache: a randomized, double-blind, placebo-controlled trial. Acta Anaesthesiol Belg 2011; 62:143-6.

17. Okpala BC, Eleje GU, Ikechebelu JI, Ofojebe CJ, Ejikeme TB, Nwachukwu CE, Okpala AN. A double-blind placebo controlled trial on effectiveness of prophylactic dexamethasone for preventing post- dural puncture headache after spinal anesthesia for cesarean section. J Matern Fetal Neonatal Med 2020:14:1-6. https://doi.org/10.1080/14767058.2020.1818719

18. Yang B, Li DL, Dong P, Zhang XY, Zhang L, Yu JG. Effect of dexamethasone on the incidence of post-dural puncture headache after spinal anesthesia: a randomized, double-blind, placebo-controlled trial and a meta-analysis. Acta Neurol Belg 2015;115(1):59-67.

https://doi.org/10.1007/s13760-014-0307-x

19. Hakim SM. Cosyntropin for prophylaxis against postdural puncture headache after accidental dural puncture. Anesthesiology 2010; 113: 413-20.

https://doi.org/10.1097/ALN.0b013e3181dfd424

20. Stein MH, Cohen S, Mohiuddin MA, et al. Prophylactic vs therapeutic blood patch for obstetric patients with accidental dural puncture - a randomized controlled trial. Anaesthesia 2014;69:320-6.

https://doi.org/10.1111/anae.12562
21. Russell IF. A prospective controlled study of continuous spinal analgesia versus repeat epidural analgesia after accidental dural puncture in labour. Int J Obstet Anesth 2012;21:7-16. https://doi.org/10.1016/j.ijoa.2011.10.005

22. Orbach-Zinger S, Jadon A, Lucas DN, Sia AT, Tsen LC, Van de Velde M, Heesen M. Intrathecal catheter use after accidental dural puncture in obstetric patients: literature review and clinical management recommendations. Anaesthesia 2021. https://doi.org/10.1111/anae.15390

\section{POPUNKCINIŲ GALVOS SKAUSMU巳 RIZIKOS VEIKSNIAI, KLINIKINE் IŠRAIŠKA IR PREVENCIJA AKUŠERIJOJE M. Kalinauskas, M. Juotkutė}

Raktažodžiai: analgezija, galvos skausmas po epidurinès nejautros, galvos skausmas po spinalinès injekcijos, akušerinè anestezija.

Santrauka

İvadas. Pastaraisiais dešimtmečiais daugèja moterų, kurios gimdymui renkasi epidurinę arba spinalinę nejautrą. Kartu didejja ir komplikacijų po procedūros rizika. Popunkciniai galvos skausmai (PPGS) yra viena iš dažniausių komplikacijų po netyčinio kietojo dangalo pradūrimo.

Darbo tikslas - apžvelgti PPGS dažniausius rizikos veiksnius, klinikinę išraišką ir prevenciją akušerijos skyriuje.

Tyrimo medžiaga ir metodai. Literatūros šaltinių paieška atlikta tarptautinèse medicinos duomenų bazèse PubMed, Google Scholar. I apžvalgą ịtraukti anglų kalba publikuoti atsitiktinių imčių tyrimai, metaanalizès, retrospektyviniai, prospektyviniai tyrimai ir sisteminès literatūros apžvalgos, susijusios su PPGS.

Rezultatai. Netyčinio dangalo pradūrimo atvejų per neuroaksialinę anesteziją literatūroje pateikiama sąlyginai nedaug - 0,11,5 procento. PPGS yra tikètina komplikacija po lumbalinès punkcijos. Jie pasireiškia galvos skausmu per 5 dienas po punkcijos dèl žemo smegenų skysčio slėgio. Skausmas dažnai apima abu galvos šonus, lokalizuojasi kaktinejje ir pakaušinejje srityse. Gali pasireikšti tokie simptomai, kaip regejjimo ar klausos sutrikimas, kaklo skausmas ar pykinimas. Iprastai simptomai praeina savaime per dvi savaites. Rizikos veiksniai PPGS yra koreguojami (injekcijos technika ir anesteziologo patirtis) ir nekoreguojami (něštumas, mažas kūno masės indeksas, dehidratacija, anamnezèje PPGS). PPGS prevencijos tikslas yra nustatyti su šia būkle susijusius rizikos veiksnius ir juos koreguoti. Pagrindiniai būdai tą padaryti yra tinkama įranga ir patirtis, konservatyvūs būdai, morfino suleidimas ị epidurinị tarpą, intraveninis deksametazonas arba kosintropinas, epidurinis kraujo pleistras ir intratekalinis kateteris.

Išvados. 1. PPGS pasireiškia ortostatiniu galvos skausmu. Galimi regejjimo, neurologiniai, klausos ir kiti simptomai. 2. Jaunos néščiosios, turinčios žemą KMI, labiau linkusios ị PPGS. 3. PPGS prevenciją sudaro rizikos veiksnių koregavimas ir tinkamas medicinos metodų taikymas.

Adresas susirašinėti: mataskalinauskas9@gmail.com

Gauta 2021-04-29 